\title{
圈 \\ Is Financial Capability Related to the Effective Use of Debt in Australia?
}

Sanja Ajzerle ${ }^{1}$, Mark Brimble ${ }^{2}$ and Brett Freudenberg ${ }^{3}$

\begin{abstract}
Australians' high use of personal debt is, in part, attributable to the relaxation of the financial services regulation. There is concern that while debt has the potential to increase a person's wealth, if used ineffectively it can have the opposite effect. This paper details a study of 680 Australians to ascertain whether their financial capability is related to the effective use of personal debt. The findings suggest that it appears people with greater financial capability are more likely to use debt effectively.
\end{abstract}

Keywords: financial capability, financial literacy, effective debt, personal debt

JEL Classification: D14; E51

Acknowledgement: The authors would like to thank participants at the 2013 Financial Product Complexity and the Limits of Financial Literacy Conference for their comments on an earlier version of this paper.

\footnotetext{
${ }^{1}$ Griffith University

${ }^{2}$ Correspondence to Associate Professor Mark Brimble, Griffith Business School, Griffith University, Brisbane, Queensland, email: m.brimble @griffith.edu.au

${ }^{3}$ Griffith University
} 


\section{Introduction}

Unlike previous generations, today people use debt as a preferred payment method to purchase everything from investments to consumer goods including holidays, motor vehicles, furniture, groceries or services (Kamleitner \& Kirchler 2007). However, there is concern about the extent that people plan their spending habits and the level of their borrowings (Starr 2007), and the types of debt people are incurring. The Australian Bureau of Statistics (ABS) (2009) identified that while 55 per cent of debtor households incurred personal debt (such as credit card debt) only 12 per cent had investment debt.

This raises the question of how effectively debt is being used by consumers. If used effectively debt has the potential to be able to assist with increasing a person's wealth, however, if used ineffectively the opposite can occur. Despite this commonly accepted position, little is known about how to measure effective use of debt, nor what traits differentiate individuals who are able to use debt effectively, as opposed to those who can't. Previous research concerning debt has focused on credit card misuse (Norvilitis \& Santa Maria 2002) and banks' lending policies or financial deregulation (Jacobsen \& Naug 2004; Griffiths 2007; Worthington 2008; Green et al. 2009;). Recent research links personality traits, financial knowledge and locus of control to indebtedness (Perry 2008).

It has been argued that individuals with comprehensive financial knowledge have a tendency to manage their personal finances more responsibly, resulting in better financial outcomes (Perry \& Morris 2005). Monticone (2010) reported on the correlation that exists between financial literacy and planned spending, budgeting, decision-making, improved cash management and the level of personal wealth holding.

However, the mere knowledge and understanding of personal finance without using and implementing that knowledge is not sufficient for an individual to effectively manage personal debt (Huston 2010). For that reason, Huston (2010) distinguishes between financial literacy and financial capability. Financial literacy is best measured by determining the level of an individual's financial knowledge, and financial capability is measured by determining the application of that knowledge.

There is an absence of financial empirical literature examining consumers accumulating effective and ineffective personal debt in Australia. In particular, there has been no Australian empirical study concerning whether there is a relationship between a person's financial capability and their effective use of debt. Adding to this body of knowledge should further our understanding of how debt is used by Australian consumers and the potential influence of financial capability. The results should therefore inform financial educators, financial advisers, regulators and credit providers.

This paper details the results of an Australian survey of 680 consumers and explores their use of different types of personal debt and their financial capability. It was found that those individuals with higher financial capability use debt more effectively: however, overall effectiveness by all participants is not high.

The remainder of the paper is structured as follows. The next section contains a review of the literature, followed by a discussion of the data and method. This is followed by the results and discussion, with the final section of the paper containing the limitations and future research possibilities before the paper concludes. 


\section{Theoretical Background}

\section{Personal Debt in Australia}

Personal debt has become a growing concern in Australia (Worthington 2006, 2009; Griffiths 2007; Green et al. 2009; Meng \& Mounter 2009;). This is reflected by the fact that over the last two decades personal debt has risen at a faster rate than the growth of consumers' income (Figure 1), with an upward trend in debt to income ratios from 40.5 percent in June 1980 to 156.4 percent in June 2007 (RBA 2012a). Although personal debt accumulation temporarily reduced to 148.8 percent of disposable income during the Global Financial Crisis in 2009, it has been inconsistent since that time (Guest 2011; RBA 2012a). Compared to other countries in the developed world (such as the United States of America, Canada and the United Kingdom), Australia's ranked position ascended from the lower end of the household disposable income scale to the higher end (Worthington 2009; Reserve Bank of Australia (RBA) 2012a).

Figure 1: Debt to income ratio (\%) in Australia, June 1980 to June 2012

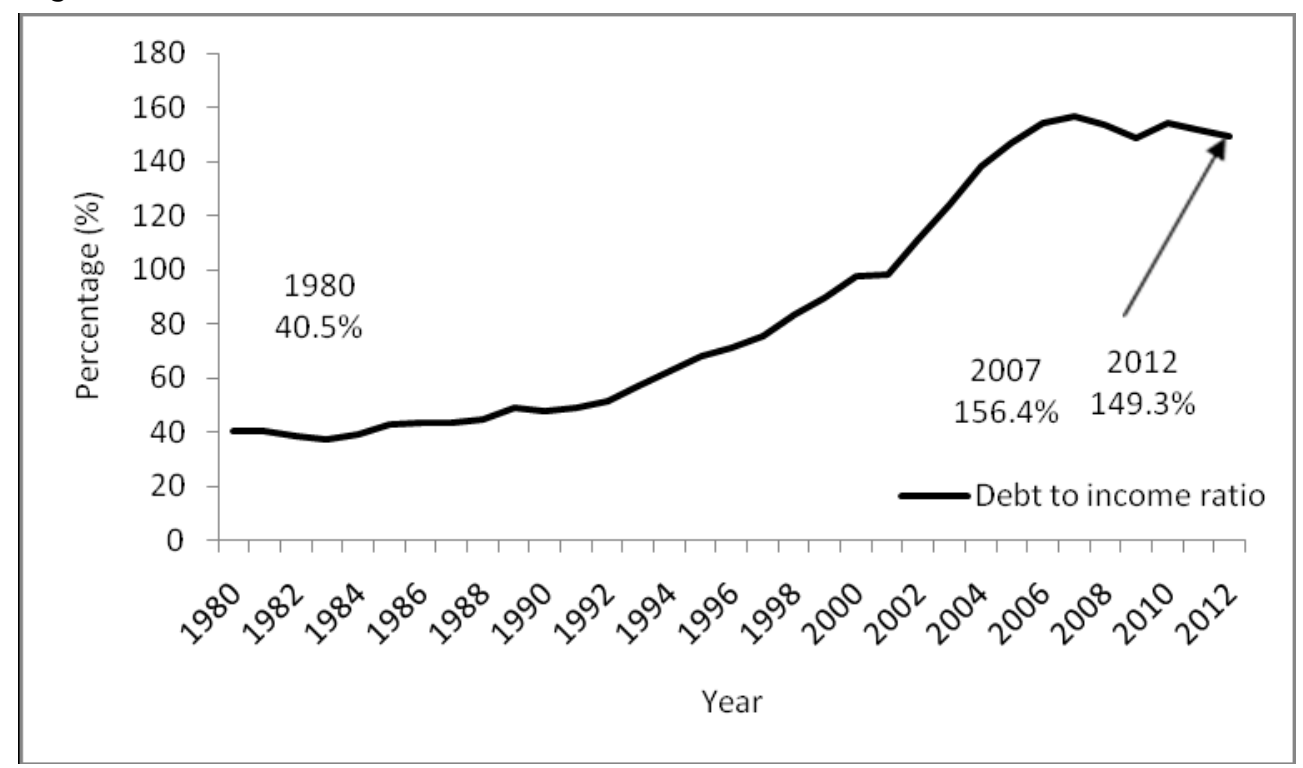

Source: RBA (2012a). Statistical tables: Household finances - selected ratios B21

Correspondingly, access to credit has increased with the number of credit cards issued in Australia growing from 6.5 million in June 1994 to 14.9 million in June 2012 (RBA 2012b). This means that approximately 36.7 percent of Australians had credit cards in 1994, compared to 66.6 percent in 2012 (ABS 2002, 2008). Furthermore, the monetary value of purchases and cash withdrawals obtained through credit cards increased approximately 11 fold during the same period (RBA 2012b).

Perhaps even more concerning is that Australian consumers are spending up to 50 percent of their after tax income meeting minimum repayment demands on existing personal debt including mortgages (Griffiths 2007). This is approximately 1.7 times higher than the 30 percent of consumers' gross income, which is the historical benchmark for permissible debt servicing ratios (Griffiths 2007). 


\section{Effective Use of Debt}

A number of authors have argued that, if used properly, personal debt can simultaneously bring prosperity to the financial institutions and to consumers (Berg 2005; Watkins 2009). However, personal debt is not without risks. When used inappropriately, personal debt has a tendency to be the most important contributing factor to distress, financial difficulty or even bankruptcy, particularly when experiencing cash flow difficulties (Baek \& Hong 2004; Berg 2005; Cava \& Simon 2005; Kamleitner \& Kirchler 2007).

This raises the question of how effectively is debt used. The literature raises a range of issues that influence the use of personal debt, including: demographic factors and weak money management skills (especially with credit card usage) (Lea et al. 1995; Norvilitis et al. 2003); psychological factors such as instant gratification (Lea et al. 1995; Dellandale \& Saporoschenko 2004; Griffiths 2007) and lifestyle (Lea et al. 1995; Norvilitis \& Santa Maria 2002; Brennan, Zevallos, \& Binney 2011); and the influence of others, such as family or friends (O’Loughlin \& Szmigin 2006; Legge \& Heynes 2009).

We are unable, however, to identify any work that seeks to establish what effective use of debt is, or what factors contribute to it. This paper seeks to conduct a preliminary examination to what is the effective use of debt within the framework of financial knowledge and capability.

\section{From Financial Knowledge to Financial Capability}

The terms 'knowledge', 'literacy' and 'capability' in relation to personal finance are often used interchangeably in the media and research, however each term has a discrete meaning (Huston 2010). General 'literacy' represents a set of fundamental skills required to read, write and tally figures (Coonan \& Clitheroe 2004). A basic level of numeracy and literacy skills is necessary in order to read contract terms, understand bank statements, and engage in basic financial activities such as budgeting (Coonan \& Clitheroe 2004). 'Financial knowledge' represents an understanding of financial matters that assist consumers with financial decision making (Huston 2010). 'Financial literacy' is based on consumers' knowledge and confident financial performance regarding budgeting, spending, borrowing and investing (ANZ 2005). 'Financial capability' is a perception of consumers' behaviour regarding financial matters, consisting of four financial domains: managing money; planning ahead; choosing the most suitable financial debt instruments and products; and staying informed by seeking information (Atkinson et al. 2007). This paper is concerned with financial knowledge and capability in relation to debt, each of which is examined below.

\section{Financial Knowledge}

Financial deregulation in Australia has led to a diversity of financial products available, although this diversity has increased the complexity of financial decision making processes around the most basic of financial products (Hall 2008).

Consequently, consumers need a good level of financial knowledge to invest wisely and manage personal debt levels in a manner which may result in a better financial outcome (Perry \& Morris 2005). Financially literate consumers tend to have a better understanding of the forms and functions of financial debt instruments (Pellinen et al. 2011). Further, financially knowledgeable consumers have a tendency not only to implement that knowledge (Pellinen et al. 2011) but also to search for the vital information required and engage the services of other professionals when needed (Perry \& Morris 2005).

Several authors have linked financial knowledge with consumers' responsible financial behaviour, often demonstrated by considering the needs of family and friends when making 
financial decisions (Perry 2008; Pellinen et al. 2011). For example, Hoelzl and Kapteyn (2011) pointed to possible challenges faced by 'blended' families that consist of partners and children from previous relationships. Critical attributes to responsible financial behaviour includes controlling spending, saving and the timely payment of personal debts and bills (Perry \& Morris 2005). Monticone (2010) also observed this relationship between financial knowledge, responsible financial behaviour, and wealth accumulation. In a study based on a survey data of 7,768 Italian households and 19,551 individuals conducted by the Bank of Italy, Monticone (2010) found a correlation between planned spending, budgeting, financial decision making, cash management controls and the level of personal wealth accumulation. Further, in a study of 290 UAE-national investors, Hassan Al-Tamini and Kalli (2009) found that demographic factors such as income, education, occupation and the level of financial knowledge affected investment decisions.

In contrast, consumers with limited financial knowledge combined with the acceptance of personal debt and lack of understanding can lead to an inability to make informed decisions (Norvilitis et al. 2006). This is because financially illiterate consumers have a tendency to make poor financial choices resulting in imprudent personal debt with high borrowing costs (Monticone 2010). Also, debt instruments are becoming more complex as financial institutions create new product ranges in order to satisfy demands of consumers with different demographic characteristics (Atkinson et al. 2007; Remund 2010). Furthermore, a number of consumers may be willing to 'trade short term gains for long terms cost' when preference is given to consumption in the present whilst consideration of debt repayment is left for a future time (Brougham et al. 2011, p. 80). Further, Norvilitis and Santa Maria (2002) found that students with extremely basic or non-existing financial knowledge as well as weak money management do not understand the implications of accumulating credit card debt, and may be at risk of becoming over indebted adults (Perry \& Morris 2005). In a study of 583 individuals classified as non-debtors, mild debtors or serious debtors, Lea et al. (1995) found that participants with poor money management were overcommitted with personal debt. For example, poor money management can be exhibited by lack of budgeting to monitor spending, having no savings to assist with unexpected expenses or having unrealistic expectations of future income (Walker 1996). In a study of 100 females aged 18 to 43 who were mothers of new babies, Walker (1996) found that those participants who implemented budgeting techniques to control additional expenditure due to a new baby experienced lower financial difficulties than those without a budget. This illustrates the potential link of personal debt level with using tools to assist with money management.

\section{Financial Capability}

Originally, financial literature used the terms 'financial capability' and 'financial literacy' equally, however in recent years the term financial capability has been given more weight as it also emphasises individuals' financial action and behaviour (Atkinson et al. 2007).

Furthermore, it has been argued that consumers' ability to handle personal finances is linked with budgeting skills, as budgeting requires their awareness of income and expenditure levels (Coonan \& Clitheroe 2004). Also, budgeting may assist to control spending, resulting in reduced personal debt levels as it helps consumers to differentiate between their 'needs and wants' (Coonan \& Clitheroe 2004), and the possible consequences of overspending (Brougham et al. 2011).

Evidence suggests that consumers do seek assistance regarding financial product selection, with preference for the information source given to family, friends, media, the internet, and seminars; as opposed to finance professionals (Coonan \& Clitheroe 2004). 


\section{Measuring Financial Knowledge and Capability}

In Australia, the first national survey that measured and established the benchmark of financial literacy of Australian residents was commissioned by the ANZ Bank in 2002 (ANZ 2003). The study found that the majority of Australian residents are financially literate with $80 \%$ feeling well informed when making decisions. In addition a relationship between participants' socioeconomic factors and the level of financial literacy was found (ANZ 2003). Further, the research found the least financially literate were participants who were: of low education; unemployed; unskilled; earning less than $\$ 20,000$ per annum,; with a savings level under \$5,000; single people; young participants (18-24 years old); or older (over 70 years) (ANZ 2003). The ANZ Bank commissioned two further studies in 2005 and 2008, with the 2005 study providing similar results except that performance of maths questions declined (ANZ 2008).

Research conducted in several overseas countries also correlated socio economic factors with limited financial knowledge, capability and literacy (Atkinson \& Messy 2012).

Despite the prior research in this field no study to date has examined the issue of how individual financial capability influences the degree to which personal debt is used effectively. It is this gap that this study seeks to address.

\section{Data and Method}

This paper examines the research question 'How does financial capability affect the effectiveness of personal debt obtained?' using a mixed methods approach. The research is conducted in two stages by implementing qualitative methods in Stage One through semi structured interviews and focus groups to inform the development of a survey used in Stage Two.

\section{Stage One: Interviews}

Stage One explored participants' opinions and personal experiences about debt, factors influencing debt and their insights on managing and controlling different types of personal debt. This was an important step given the lack of a consensus definition in the literature of 'effective use of debt' and this method allowed for a better understanding of the research topic (Anderson 2010). A total of 22 (15 with finance professionals and 7 with consumers) semistructured interviews were conducted. A further 13 consumer individuals shared their beliefs and experiences in regards to debt by participating in three focus groups, providing a total of 35 participants. A range of media were used to gain participants, including professional networks, employers related to the host institution and the researcher, community groups, and social networking.

The selection of finance professional participants was based on purposive sampling (Palys 2008) from various finance occupations including bankers, financial planners, financial counsellors, mortgage brokers and university academic personnel specialising in finance subjects. The selection of the consumer participants was based on convenience sampling (Anderson 2010). This facilitated a variety of opinions and experiences from participants, and hence a number of consumer participants from different age groups, gender and nationality were invited to take a part in the research.

Of interest was how participants perceived how debt could be used both effectively and ineffectively. All finance professional participants identified the importance of understanding the difference between effective and ineffective debt although three of them associated effective debt with 'good debt', and ineffective debt with 'bad debt'. 
Twelve finance professionals associated effective debt with the borrowing of funds to purchase an asset base that has the potential to grow in value over time. They pointed to borrowing for investment purposes, such as shares, as an example of effective debt. This was due to a number of factors, such as tax deductions, capital growth and dividends received. Furthermore, ten finance professionals pointed out that for many Australians the purchase of a family home is the most common example of effective debt. That is because by replacing rental expenses with mortgage repayments, they will own an asset that will most likely be worth more than what they paid for it after finalising the mortgage repayments. Similarly, nine consumer participants associated the purchase of a family home as effective use of debt.

Both finance professional participants and consumer participants displayed a similar understanding of what the difference between effective and ineffective debt was:

'Ineffective debt in the long term will decrease your standard of living and effective debt will increase your standard of living.' (Female: Consumer)

Ten finance professionals equated ineffective debt with borrowings obtained for the purchase of products and services consumed quickly and with no residual value, but with an outstanding debt:

'When you buy something that you want and there is no income coming from that, it's just a discretionary expense, a consumable. It's gone, but the debt is still there.'(Male: Professional)

Finance professional participants provided three instances of ineffective use of debt. Firstly, motor vehicle loans for both personal and business purposes. Three participants pointed out the negative experiences with business motor vehicle leases. Even though the expenses were tax deductible and depreciation benefits obtained, they still lost a considerable amount of money:

'...you know like my Mercedes, $\$ 115,000$ and when I drove it down my driveway it was worth $\$ 75,000$ and when I sold it I got $\$ 55,000$ after 4 years or so. Ok, I leased it off the company but even so it's still a hell lot of money...You're making the finance company richer with the lease. Ok you get tax breaks but it's not worth it.' (Male: Professional)Secondly, seven finance participants indicated borrowing for holidays as another example of ineffective debt which can transform a bargain holiday into an expensive holiday:

'...but they have to realise, that if they're borrowing money for a holiday that they've got to pay interest as well. So it turns a cheap holiday into a dear holiday.' (Male: Professional)

Finally, eleven finance participants pointed to credit cards as another example of ineffective debt, and a form of debt that may entice people to overspend:

'...it's really tempting...\$1,200 or something sitting there in credit...and sees things on special and think...what a bargain it would be.' (Female: Professional)

However, four finance professionals disagreed and thought that credit card debt can be classified as a form of effective debt when used properly. This was due to the benefits provided such as frequent flyers points and 55-days interest free periods. Although they stressed the importance of paying the outstanding balance in full each month to avoid paying any interest, as otherwise the credit card debt quickly becomes ineffective debt:

'If you use a credit card properly and you do accumulate some rewards, for example frequent flyer points or whatever and you are disciplined about paying the 
debt off at the end of the month, so you don't pay any interest, then in that sense that type of debt can be useful.' (Male: Professional)

Furthermore, three finance professionals expressed concerns that many have a limited or nonexisting understanding of the difference between effective and ineffective personal debt, and they are unaware of what ineffective debt is actually costing them:

'They have no comprehension of how much an item is actually costing them. So they go off and buy a TV for $\$ 599$ and don't realise that it's probably costing them $\$ 2,000$ by the time they've paid interest.' (Female: Professional)

Only one consumer participant noted the importance of professional help in appreciating the difference:

'I was only made aware of effective and ineffective debt when we went to our financial planner because I didn't realise there was a difference, and having been aware of that difference we were able to organise our financials much better.' (Female: Consumer)

\section{Stage Two: Survey}

The understanding developed through Stage One was the foundation of the survey questionnaire developed for Stage Two. The survey questionnaire was reviewed and pilot tested by ten individuals for readability, ambiguity, jargon and bias (Andrews et al. 2003).

The questionnaire was divided into three major sections. The first section focused on financial management skills including managing money, planning, choosing financial products, and staying informed. Participants were required to select an answer to each question that was most suitable for their situation, with the option to provide additional responses. The purpose of this section was to collect data that would allow for the comparison of participants according to those using debt effectively or ineffectively, and participants with high or low financial capability skills.

The second section was in two parts. The first examined participants' perceptions of their personal debt utilisation, including factors influencing debt level such as: convenience; tax benefits; financial management skills (financial capability); influence of children, family and friends; and the level of participants' responsibility for their actions (locus of control). The second part consisted of debt related questions ordered by type of debt with each participant asked to answer those questions if they actually had that particular type of debt. Survey participants indicated their responses by using a 5 point Likert-style scale of choices including strongly disagree, disagree, neutral, agree, strongly agree plus options for not sure and not applicable.

The final section collected demographic information including gender, age, marital status, number of children, education, occupation, income and the approximate current market value of their assets.

The target population for the Stage Two surveys included individuals with a finance background such as financial planners, financial counsellors, accountants and bankers, and also Australian consumers with various other occupations, fundamentally categorised according to the Australian and New Zealand Standard Classification of Occupations (ABS, 2011). Email invitations with the link to the web designed survey were sent to the target population who were recruited on a random basis through the Financial Planning Association, Institute of Public Accountants, Professional Investment Services, Financial Counselling Australia, and Australian Yellow Pages. In addition, the research was promoted on Griffith 
University's website, providing students and university employees with the link to complete the web based survey.

From this process, a total of 823 participants commenced the survey with 680 entirely completing it, demonstrating 82.6 percent of usable survey responses. The sample is well distributed across gender, age, martial status, children, income and occupation (Table 1). There is however a greater proportion of participants with postgraduate education (22\%) and generalisation of the results needs to take this into consideration.

\section{Results and Discussion}

Financial capability questions were designed to measure participants' financial behaviour including managing money, planning ahead, choosing financial products, staying informed and obtaining assistance when required. Responses to these questions were used as a basis to generate a Financial Capability Score (FCS) for each participant with Likert scale questions numerically coded and averaged. Only responses to those questions were used as a basis to generate the FCS. For example, the survey question 'I consulted an accountant or financial advisor prior to obtaining the vehicle loan or lease' was classified as a capable financial behaviour response. Hence, each participant that had 'strongly agree' with this statement was coded with 5 , whereas responses 'strongly disagree' were coded with $1 .{ }^{4}$

The sample was then split at the median FCS which was 3.33 out of 5 . This resulted in 344 participants classified as having higher financial capability and 336 participants classified with lower financial capability. Table 2 provides summary descriptive statistics for the sample when split at this median point. This shows gender to be split evenly by financial capability, but suggests, in line with prior research, that a greater proportion of older, lower income and less educated participants are in the lower capability group. It also appears there are a greater percentage of those in a relationship and working in the finance and medical industries have a higher capability score. It is not the purpose of this paper to examine these dynamics in detail; however it does provide a picture of the sample and supports the approach to disaggregating the data as the results are broadly in line with the prior research.

In order to gain an understanding of the relationship between different types of accumulated personal debt and its effective or ineffective utilisation, participants were asked a range of questions, scattered throughout the survey, measuring their attitude towards different debt categories. Only responses to those questions were used as a foundation to generate the 'Effective Debt Score' (EDS), which was used to measure the effectiveness of different types of debt. Effectiveness was determined in terms of using debt with the tendency to increase an individual's wealth (such as purchasing something that has the potential to increase in value over time or increasing the standard of living in the long term and/or being prudent in how the debt is acquired). For example, the survey question 'I am easily influenced by advertising on TV to purchase items with debt' was classified as an ineffective use of debt. Hence, each participant that had 'strongly agree' with this statement was coded with 1 , whereas responses 'strongly disagree' were coded with 5 . The 45 questions used to compile the EDS are detailed in the Appendix. The sample was then split at the median EDS which was 3.28 out of 5.

\footnotetext{
${ }^{4}$ The not sure and not applicable responses were treated separately and were not coded into averages for the EDS for FCS scores.
} 
Table 1: Descriptive statistics

\begin{tabular}{|c|c|c|c|}
\hline & & No. & Percentage \\
\hline \multirow[t]{2}{*}{ Gender } & Males & 328 & 48 \\
\hline & Females & 352 & 52 \\
\hline \multirow[t]{5}{*}{ Age } & $18-24$ & 158 & 23 \\
\hline & $25-34$ & 173 & 25 \\
\hline & $35-44$ & 163 & 24 \\
\hline & $44-59$ & 145 & 21 \\
\hline & $60+$ & 41 & 6 \\
\hline \multirow[t]{3}{*}{ Marital status } & Married / Defacto & 418 & 61 \\
\hline & Single & 219 & 32 \\
\hline & Separated/Divorced/Widowed/ Widower & 43 & 6 \\
\hline \multirow{2}{*}{$\begin{array}{l}\text { Children } \\
\text { under } 18\end{array}$} & No & 448 & 66 \\
\hline & Yes & 232 & 34 \\
\hline \multirow[t]{5}{*}{ Education } & Year 10 of High School & 17 & 3 \\
\hline & Year 12 of High School & 112 & 16 \\
\hline & Vocational Education (e.g. TAFE) & 126 & 19 \\
\hline & University (Bachelor Degree) & 277 & 41 \\
\hline & Postgraduate Studies (Master or PhD) & 148 & 22 \\
\hline \multirow[t]{12}{*}{ Occupation } & Financial services & 50 & 7 \\
\hline & Accountants & 75 & 11 \\
\hline & Financial counsellors & 25 & 4 \\
\hline & Professionals & 44 & 6 \\
\hline & Clerical and administrative workers & 170 & 25 \\
\hline & Technicians and trade workers & 55 & 8 \\
\hline & Business proprietors \& self-employed & 10 & 1 \\
\hline & Medical workers & 17 & 3 \\
\hline & Sales workers & 41 & 6 \\
\hline & Students & 115 & 17 \\
\hline & Education (lecturers) & 47 & 7 \\
\hline & Other & 31 & 5 \\
\hline \multirow{6}{*}{$\begin{array}{l}\text { Income } \\
\text { (Individual) }\end{array}$} & $\$ 0-\$ 18,200$ & 106 & 16 \\
\hline & $\$ 18,201-\$ 37,000$ & 98 & 14 \\
\hline & $\$ 37,001-\$ 80,000$ & 235 & 35 \\
\hline & $\$ 80,001-\$ 180,000$ & 156 & 23 \\
\hline & $\$ 180,000+$ & 59 & 9 \\
\hline & Not applicable & 26 & 4 \\
\hline \multirow{6}{*}{$\begin{array}{l}\text { Income } \\
\text { (Partner) }\end{array}$} & $\$ 0-\$ 18,200$ & 96 & 14 \\
\hline & $\$ 18,201-\$ 37,000$ & 66 & 10 \\
\hline & $\$ 37,001-\$ 80,000$ & 154 & 23 \\
\hline & $\$ 80,001-\$ 180,000$ & 115 & 17 \\
\hline & $\$ 180,000+$ & 9 & 1 \\
\hline & Not applicable & 240 & 35 \\
\hline
\end{tabular}

This table presents summary descriptive statistics of a sample of 680 consumers 
Table 2: Sample split by financial capability

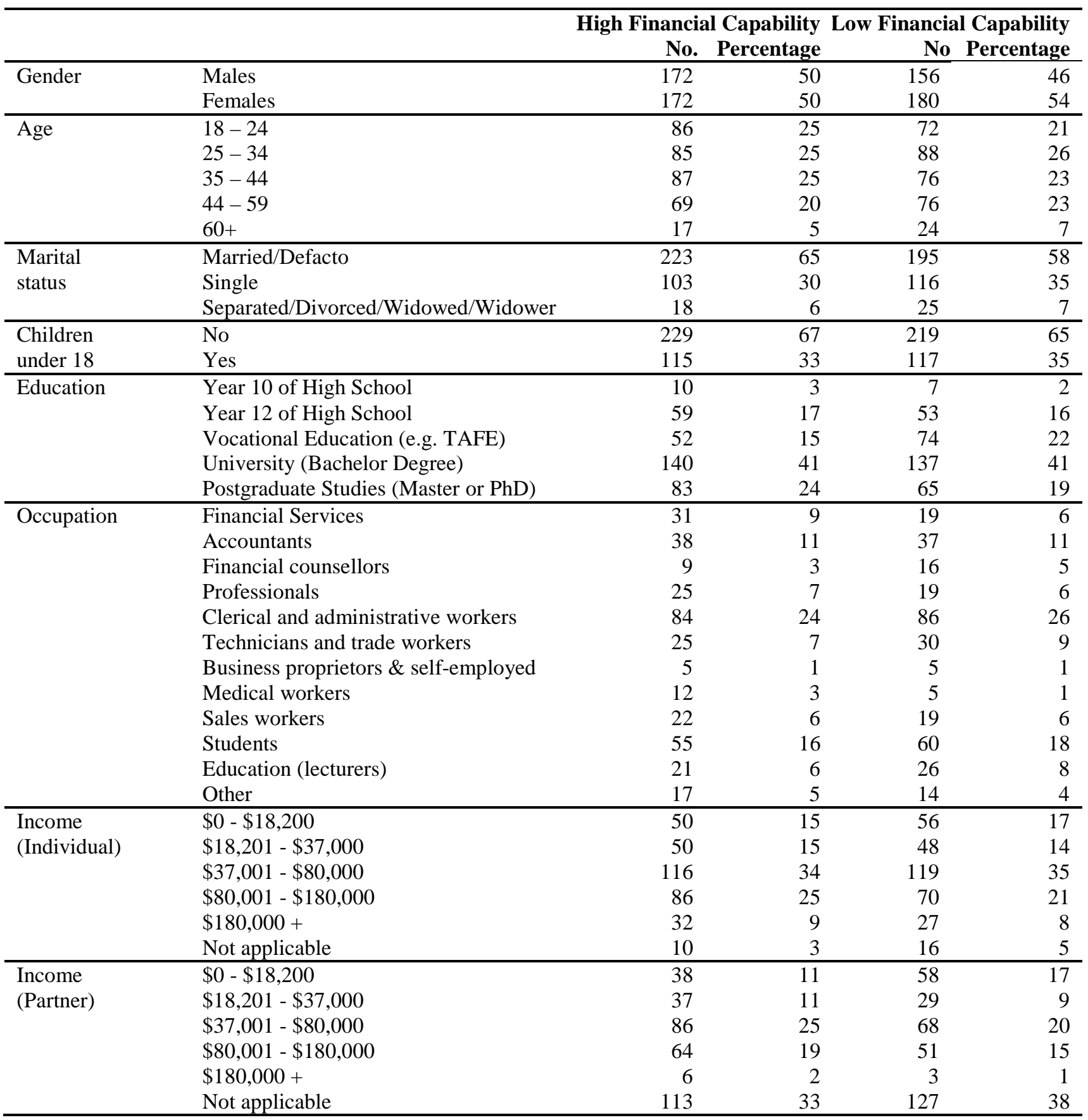

This table presents summary descriptive data for our sample when disaggregated by the median financial capability score (FCS). The FCS is calculated from a number of questions contained in the survey which indicated (based on the prior literature) financial capability

\section{Financial Goals}

In relation to financial goals, a majority of participants had financial goals with only $9.2 \%$ of lower and $2.9 \%$ of higher financial capability participants not having any financial goals. Approximately $97.1 \%$ of those with higher financial capability reported having financial goals and $33.1 \%$ as having those goals written down. Of these, $54 \%$ were females, $68 \%$ were married, 26\% were aged 35 to $44,58 \%$ were without children, $64 \%$ had university qualifications, 32\% worked in the financial industry, and 32\% earned between \$37,001 and 
$\$ 80,000$ per annum. Their EDS of 3.74 was the highest and significantly higher than the score of those with lower financial capability.

In comparison, approximately $90.8 \%$ of those participants with lower financial capability also had financial goals with $27.7 \%$ having these written down. The participants with indicative lower financial capability that did not have any financial goals were most likely to be aged 18 to 24 (35\%), without children (71\%), with university education (58\%) and earning between $\$ 0$ and $\$ 18,200$ (45\%). Their EDS of 2.77 was the lowest and significantly so (Table 3).

Overall, the results suggest that those with written down financial goals are more financially capable and use their debt more effectively.

Table 3: Comparison of EDS with financial goals

\begin{tabular}{lrrrr}
\hline & $\begin{array}{c}\text { Higher } \\
\text { Financial } \\
\text { Capability (\%) }\end{array}$ & $\begin{array}{c}\text { Lower } \\
\text { Financial } \\
\text { Capability (\%) }\end{array}$ & $\begin{array}{c}\text { Higher } \\
\text { Financial } \\
\text { Capability }\end{array}$ & $\begin{array}{c}\text { Lower } \\
\text { Financial } \\
\text { Capability }\end{array}$ \\
\cline { 2 - 5 } & & & & EDS \\
\hline I have not written down financial goals & 64.0 & 63.1 & $3.61^{* * *}$ & 3.03 \\
I have written down financial goals & 33.1 & 27.7 & $3.74^{* * *}$ & 3.08 \\
I don't have any financial goals & 2.9 & 9.2 & $3.64^{* *}$ & 2.77 \\
\hline
\end{tabular}

Effective Debt Score is the score below the median value ' 3.28 ' is regarded as indicating less effective debt utilisation whereas score above ' 3.28 ' is regarded as indicating more effective debt utilisation). '**' denotes significance at the $5 \%$ level, '***' denotes significance at $1 \%$ level

\section{Managing Personal Finances}

In terms of managing their finances, $81.4 \%$ of those participants with suggestive higher financial capability reported managing their own finances, and of these, $39.2 \%$ found that enjoyable. Of these, 59\% were females, $72 \%$ were married, 35\% were aged 18 to 24 and 35\% were aged 25 to 34, 67\% had university qualifications, and 34\% worked in financial fields. Those participants also had higher annual income with 25\% earning between \$80,001 and $\$ 180,000$, and $9 \%$ earning in excess of $\$ 180,000$ per annum. They had the highest EDS of 3.75 (Table 4). The remaining 14\% reported their preference to manage financial matters by themselves but needing assistance.

In contrast, of those participants with indicative lower financial capability, $69.4 \%$ managed their own finances, with $29.9 \%$ enjoying doing so and $22.9 \%$ reporting requiring assistance. Of those that enjoyed managing their finances, most had obtained university degrees (87\%) and worked in the financial industry (42\%), earning higher annual incomes. In particular 34\% reported earnings between $\$ 80,001$ and $\$ 180,000$ whilst $18 \%$ had annual income over $\$ 180,000$. They were predominantly (66\%) aged 45 to 59 (36\%) with an EDS of 3.17 or better.

Overall, those with higher capability had higher EDSs and were more confident with managing their financial affairs and were more likely to enjoy doing so. 
Table 4: Comparison of EDS with managing personal finances

\begin{tabular}{|c|c|c|c|c|}
\hline & $\begin{array}{c}\text { Higher } \\
\text { Financial } \\
\text { Capability (\%) }\end{array}$ & $\begin{array}{c}\text { Lower } \\
\text { Financial } \\
\text { Capability (\%) }\end{array}$ & $\begin{array}{c}\text { Higher } \\
\text { Financial } \\
\text { Capability }\end{array}$ & $\begin{array}{c}\text { Lower } \\
\text { Financial } \\
\text { Capability } \\
\end{array}$ \\
\hline & & & \multicolumn{2}{|c|}{ EDS1 } \\
\hline I would rather someone else do it & 6.8 & 3.2 & $3.48^{*}$ & 3.10 \\
\hline $\begin{array}{l}\text { I would rather do it myself but need } \\
\text { assistance }\end{array}$ & 14.0 & 22.9 & $3.51^{* * *}$ & 2.75 \\
\hline I manage my finances & 42.2 & 39.9 & $3.62^{* * *}$ & 3.06 \\
\hline $\begin{array}{l}\text { I manage my finances and enjoy } \\
\text { doing it }\end{array}$ & 39.2 & 29.5 & $3.75^{* * *}$ & 3.17 \\
\hline
\end{tabular}

Effective Debt Score (score below the median value '3.28' is regarded as indicating less effective debt utilisation whereas score above ' 3.28 ' is regarded as indicating more effective debt utilisation). '*' '**' denotes

significance at the $5 \%$ level, '***' denotes significance at $1 \%$ level

\section{Budgeting}

Slightly more than half of the sample did not have a budget, and that was evenly spread across the high and low capability groups. However, slightly more of the high capability group reported following the budget they had prepared compared to those with lower financial capability (36.6\% vs 31.5\%). Interestingly, participants with indicative higher (3.70) and lower (3.15) financial capability reported the highest EDS for their group, suggesting that having a budget is not related to their financial capability, nor effective use of debt (Table 5). This is counter to what is expected given the emphasis on budgeting in financial literacy programs, however this may be indicative of those individuals (financially capable) being more aware of their financial circumstances and choices irrespective of having a formal budget. Either way, those that are financially capable used their debt more effectively irrespective of their use of budgets.

Table 5: Comparison of EDS with budgeting

\begin{tabular}{|c|c|c|c|c|}
\hline & $\begin{array}{c}\text { Higher } \\
\text { Financial } \\
\text { Capability (\%) }\end{array}$ & $\begin{array}{c}\text { Lower } \\
\text { Financial } \\
\text { Capability (\%) }\end{array}$ & $\begin{array}{c}\text { Higher } \\
\text { Financial } \\
\text { Capability } \\
\end{array}$ & $\begin{array}{c}\text { Lower } \\
\text { Financial } \\
\text { Capability } \\
\end{array}$ \\
\hline & & & \multicolumn{2}{|c|}{ EDS $^{1}$} \\
\hline $\begin{array}{l}\text { I have a written budget which I } \\
\text { follow most of the time }\end{array}$ & 36.6 & 31.5 & $3.65^{* * *}$ & 3.03 \\
\hline $\begin{array}{l}\text { I have a written budget which I } \\
\text { rarely follow }\end{array}$ & 9.0 & 17.9 & $3.63^{* * *}$ & 2.94 \\
\hline I don't have a budget & 41.3 & 38.9 & $3.70^{* * *}$ & 3.15 \\
\hline $\begin{array}{l}\text { I don't need a budget as both my } \\
\text { income and expenses are low }\end{array}$ & 13.1 & 11.6 & $3.49^{* * *}$ & 2.79 \\
\hline
\end{tabular}

Effective Debt Score (score below the median value '3.28' is regarded as indicating less effective debt utilisation whereas score above ' 3.28 ' is regarded as indicating more effective debt utilisation). '**' denotes significance at the $5 \%$ level, '***' denotes significance at $1 \%$ level

\section{Meeting Unexpected Expenses}

Participants were requested to indicate how they would finance an unexpected expense of $\$ 1,000$ (as having access to liquidity or emergency money which are key strategies commonly articulated in financial literacy programs). Table 6 shows for both higher and lower capability groups the most relied upon financial resources in the case of an emergency was existing savings $(71.2 \% / 57.4 \%)$ and credit cards $(20.3 \% / 26.5)$. This also aligns with significantly 
higher effective use of debt by the higher capability group in all categories but one (increasing credit card limit).

An examination of demographic characteristics of the participants that would tend to seek financial assistance from their family and friends revealed several similarities (aged 18 to 24, single, with year 12 of high school as the highest level of education and low levels of income). Those who are unsure about how to fund unexpected costs score the lowest EDS and those who can fund this through savings obtain the highest level of financial capability.

Table 6: Comparison of EDS with meeting unexpected expenses

\begin{tabular}{|c|c|c|c|c|}
\hline & $\begin{array}{c}\text { Higher Financial } \\
\text { Capability (\%) }\end{array}$ & $\begin{array}{c}\text { Lower Financial } \\
\text { Capability (\%) }\end{array}$ & $\begin{array}{c}\text { Higher Financial } \\
\text { Capability }\end{array}$ & $\begin{array}{c}\text { Lower Financial } \\
\text { Capability }\end{array}$ \\
\hline & & & \multicolumn{2}{|c|}{ EDS1 } \\
\hline $\begin{array}{c}\text { Borrow from family } \\
\text { and friends }\end{array}$ & 4.5 & 8.0 & $3.65^{* * *}$ & 2.93 \\
\hline Use my credit card & 20.3 & 26.5 & $3.57^{* * *}$ & 3.04 \\
\hline Increase my credit & 0.6 & 2.1 & & \\
\hline $\begin{array}{l}\text { limit, if } \\
\text { necessary }\end{array}$ & & & 3.23 & 2.74 \\
\hline $\begin{array}{l}\text { Obtain a loan from the } \\
\text { bank }\end{array}$ & 0.0 & 0.6 & - & - \\
\hline Obtain a payday loan & 0.0 & 0.3 & - & - \\
\hline Use existing savings & 71.2 & 57.4 & $3.70^{* * *}$ & 3.07 \\
\hline Don't know & 0.9 & 2.4 & $2.72^{* * *}$ & 2.64 \\
\hline
\end{tabular}

Effective Debt Score (score below the median value '3.28' is regarded as indicating less effective debt utilisation whereas score above ' 3.28 ' is regarded as indicating more effective debt utilisation). '**' denotes significance at the $5 \%$ level, '***’ denotes significance at $1 \%$ level

\section{Source of Financial Information}

Table 7 shows that the most common information source is free advice obtained from family and friends for those with indicative higher (54.7\%) and lower (53.6\%) financial capability. Furthermore, those with lower financial capability were less likely to pay for financial advice (from a broker, banker, accountant or planner) and more likely not to obtain any financial information (16.7\% vs $12.2 \%)$. Again the EDSs of the high capability group are significantly greater than those of the lower group, with the highest (albeit marginally) relating to those that seek professional advice and go to seminars.

\section{Selecting Financial Debt Instruments}

Given the complexity of financial debt instruments, participants were requested to indicate all methods used when selecting financial debt instruments. Participants with higher financial capability were more actively involved in product selection, with $64 \%$ comparing product benefits amongst different lenders, 39\% searching for products online, and $24.1 \%$ reading product disclosure statements (Table 8). Notably, these scores are all higher than those for the lower capability group and reflect significantly more effective use of debt. Continuing the trend, the EDSs of the high capability group are significantly higher than those of the low capability group, with the highest score with the group which has read product disclosure statements, supporting the earlier suggestion that those who actively participate are likely to get a better outcome. 
Table 7: Comparison of EDS with source of financial information results

\begin{tabular}{lcc|cc}
\hline & $\begin{array}{c}\text { Higher } \\
\text { Financial } \\
\text { Capability } \\
(\%)\end{array}$ & $\begin{array}{c}\text { Lower } \\
\text { Financial } \\
\text { Capability (\%) }\end{array}$ & $\begin{array}{c}\text { Higher Financial } \\
\text { Capability }\end{array}$ & $\begin{array}{c}\text { Lower Financial } \\
\text { Capability }\end{array}$ \\
\cline { 2 - 5 } & & & & EDS $^{1}$ \\
\hline Financial planner / advisor & 34.0 & 25.9 & $3.79^{* * *}$ & 3.11 \\
Accountant / tax agent & 42.2 & 33.6 & $3.70^{* * *}$ & 3.09 \\
Bank & 37.8 & 35.1 & $3.72^{* * *}$ & 3.05 \\
Mortgage broker & 22.1 & 13.7 & $3.73^{* * *}$ & 3.10 \\
Financial magazines/publications & 28.8 & 20.5 & $3.72^{* * *}$ & 3.13 \\
Internet finance related sites & 32.3 & 28.6 & $3.66^{* * *}$ & 3.09 \\
Seminars & 18.0 & 12.8 & $3.78^{* * *}$ & 3.14 \\
Family or friends & 54.7 & 53.6 & $3.63^{* * *}$ & 2.93 \\
None & 12.2 & 16.7 & $3.49^{* * *}$ & 2.90 \\
\hline
\end{tabular}

Effective Debt Score (score below the median value '3.28' is regarded as indicating less effective debt utilisation whereas score above ' 3.28 ' is regarded as indicating more effective debt utilisation). ' $* *$ ' denotes significance at the $5 \%$ level, '***' denotes significance at $1 \%$ level

Table 8: Comparison of EDS with source of selection financial debt instrument

\begin{tabular}{|c|c|c|c|c|}
\hline & $\begin{array}{c}\text { Higher } \\
\text { Financial } \\
\text { Capability } \\
(\%)\end{array}$ & $\begin{array}{c}\text { Lower } \\
\text { Financial } \\
\text { Capability } \\
(\%)\end{array}$ & $\begin{array}{c}\text { Higher } \\
\text { Financial } \\
\text { Capability }\end{array}$ & $\begin{array}{c}\text { Lower } \\
\text { Financial } \\
\text { Capability }\end{array}$ \\
\hline & & & \multicolumn{2}{|c|}{ EDS $^{1}$} \\
\hline $\begin{array}{l}\text { I search for one product with the lowest } \\
\text { interest rate }\end{array}$ & 34.0 & 34.5 & $3.60^{* * *}$ & 2.94 \\
\hline $\begin{array}{l}\text { I search online for the best financial debt } \\
\text { product offered }\end{array}$ & 39.0 & 34.5 & $3.69^{* * *}$ & 3.02 \\
\hline $\begin{array}{l}\text { I compare product benefits amongst } \\
\text { different lenders }\end{array}$ & 64.0 & 50.9 & $3.69^{* * *}$ & 3.06 \\
\hline $\begin{array}{l}\text { I select one product recommended by } \\
\text { family or friends }\end{array}$ & 3.8 & 5.7 & $3.39^{* *}$ & 2.99 \\
\hline I read the product disclosure statement & 24.1 & 16.7 & $3.71^{* * *}$ & 3.07 \\
\hline None of the above & 9.3 & 15.2 & $3.67^{* * *}$ & 2.95 \\
\hline
\end{tabular}

Effective Debt Score (score below the median value '3.28' is regarded as indicating less effective debt utilisation whereas score above ' 3.28 ' is regarded as indicating more effective debt utilisation ' $* *$ ' denotes significance at the $5 \%$ level, '***' denotes significance at $1 \%$ level

\section{Summary}

The results suggest that having higher financial capability will lead to more (statistically significantly) effective use of personal debt. Those with higher financial capability (and those who use debt most effectively) are those who have written down goals, take an active role in managing their finances and enjoy doing it, have a budget that they regularly follow (or do not have one at all), have savings that can cover unexpected expenses, seek professional advice, educate themselves about financial matters, and read documentation about financial products and services prior to purchasing them. Those with lower financial capability appear to generally not be following such strategies resulting in less effective use of debt. 


\section{Limitations and Future Research}

Our research should, however, be considered in light of its limitations, particularly the fact that it is a survey of 680 people that is more highly educated on average than the general population. We also note that we have adopted specific measures of financial literacy, capability and effective use of debt that in and of themselves may not fully capture these constructs as there is no consensus on the literature in this regard.

These matters open up areas of further research, in particular the role of budgeting in financial capability, further investigation of the demographic factors, and the outcomes for those with differing levels of debt and how this ties to wealth overall. Indeed a longitudinal study of the role of debt in wealth creation, and the role of family and friends' advice, would further expand our understanding of the effective use of debt in Australia.

\section{Conclusion}

With the deregulation of the Australian financial sector there has been an increase in the variety of personal debt products, and an increasing use of and reliance on them. In particular, there has been greater access across demographics to debt, represented in part by the increase in credit card usage. Indeed, personal debt is seen as an intrinsic part of modern life. However, concerns have been raised about the levels and use of personal debt; as it can be associated with financial hardship and distress. However, not all debt is 'bad', because if debt is used effectively it can have a tendency to increase an individual's financial wealth overall. Prior research has highlighted that financial literacy, and in particular financial capability may have some relationship with people's use of and level of debt, including various demographic factors related to this. However, there is a paucity of research into whether a person's financial capability affects the effectiveness of personal debt obtained, and it is this research question that this paper sought to address.

In a study of 680 Australians details of their use of personal debt was established, including determining their financial capability as well as their tendency to use debt effectively. The findings of this research project suggest that having high financial capability is related to the effective use of debt. In particular we find that those with high financial capability are more likely to use more effective (from the perspective of wealth creation) types of debt such as home loans, investment loans and student loans. In using debt, these participants are also likely to use it more effectively, are more likely to seek professional advice, more likely to have financial goals and take personal responsibility for their financial affairs, and enjoy doing so. In contrast, those with lower financial capability appear to have lower effective use of personal debt. Such a finding is of concern, as it would suggest that the use of debt by those with lower financial capability will result in a reduction of their financial wealth overtime. This may be of concern given that those with lower financial capability are those who are older, with lower income and less education.

If government policies about increasing financial independence and wealth of its citizens (especially retirees) are to be achieved, then the results suggest that there should be greater attention to improving financial capability. The results suggest those policy makers, financial educators, financial advisers and other financial sector stakeholders, while working to build financial literacy, also need to focus on financial capability and promote engagement in financial decision making, not just awareness. It is through such improvements in financial capabilities that there could be more effective use of personal debt in Australia, and thus an increase in wealth for the individual and society overall. 


\section{References}

Andrews, D, Nonnecke, B \& Preece, J 2003, 'Electronic Survey Methodology: A Case Study in Reaching Hardto-Involve Internet Users’, International Journal of Human-Computer Interaction, vol. 16, no. 2, pp. 185. http://dx.doi.org/10.1207/S15327590IJHC1602_04

Anderson, C 2010, 'Presenting and Evaluating Qualitative Research', American Journal of Pharmaceutical Education, vol. 74, no. 8, pp. 1-7. http://dx.doi.org/10.5688/aj7408141

ANZ 2003, ANZ Survey of adult financial literacy in Australia, ANZ, Melbourne

ANZ 2005, ANZ Survey of Adult Financial Literacy in Australia, ANZ, Melbourne

ANZ 2008, ANZ Survey of Adult Financial Literacy in Australia, ANZ, Melbourne.

Atkinson, A, McKay, S, Collard, S, \& Kempson, E 2007, 'Levels of Financial Capability in the UK', Public Money \& Management, Vol. 27, no. 1, pp29-36. http://dx.doi.org/10.1111/j.1467-9302.2007.00552.x

Atkinson, A \& Messy, F (2012), 'Measuring financial literacy: Results of the OECD / International Network on Financial Education (INFE) pilot study', OECD Working Papers on Finance, Insurance and Private Pensions, no.15, OECD Publishing.

Australian Bureau of Statistics 2002, Australian National Accounts: Financial Accounts, cat. no. 5232.0, accessed, 02/08/2012 <http://www.abs.gov.au/AUSSTATS/abs@.nsf/DetailsPage/5232.0Mar\%202002?OpenDocument>.

Australian Bureau of Statistics 2008, Australian Historical Population Statistics cat. no. 3105.0.65.001, accessed, 12/09/2012 <http://www.abs.gov.au/AUSSTATS/abs@.nsf/DetailsPage/3105.0.65.0012008?OpenDocument>.

Australian Bureau of Statistics 2009, Australian Social Trends: Household debt cat. no. 4102.0, ABS Canberra.

Australian Bureau of Statistics 2011, Census Dictionary - Occupation cat. no. 2901.0 , accessed 25 October 2012, <http://abs.gov.au/ausstats/abs@.nsf/lookup/2901.0Chapter7602011>.

Baek, E, \& Hong, GS 2004, 'Effects of family life-cycle stages in consumer debts', Journal of Family and Economic Issues, vol. 25, no. 3, pp. 359-385. http://dx.doi.org/10.1023/B:JEEI.0000039946.59422.5f

Berg, DR 2005, 'Good debt - bad debt', Sackbusiness, vol. 26, no. 8, pp. 29-29.

Brennan, L, Zevallos, Z \& Binney, W 2011, 'Vulnerable consumers and debt: Can social marketing assist?', Australasian Marketing Journal, vol. 19, no. $\quad 3, \quad$ pp. 203-211. http://dx.doi.org/10.1016/j.ausmj.2011.05.007

Brougham, RR, Jacobs-Lawson, JM, Hershey, DA \& Trujilo, KM 2011, 'Who Pays Your debt? An Important Question for Understanding Compulsive Buying Among American College Students', International Journal of Consumer Studies, vol. 35, pp. 79-85. http://dx.doi.org/10.1111/j.1470-6431.2010.00923.x

Cava, GL \& Simon, J 2005, 'Household debt and financial constraints in Australia', The Australian Economic Review, vol. 38, no. 1, pp. 40-60. http://dx.doi.org/10.1111/j.1467-8462.2005.00351.x

Coonan, H \& Clitheroe, P 2004, 'Australian Consumers and Money: A Discussion Paper, The Consumer and Financial Literacy Taskforce’, Canberra.

Dellandale, S \& Saporoschenko, A 2004, 'Factors in gaining compliance toward an acceptable level of personal unsecured debt', The International Journal of Bank Marketing, vol. 22, no. 4, pp. 279-290. http://dx.doi.org/10.1108/02652320410542554

Griffiths, M 2007, 'Consumer debt in Australia: why banks will not turn their backs on profit', International Journal of Consumer Studies, vol. 31, no. 3, pp. 230-236. http://dx.doi.org/10.1111/j.14706431.2006.00524.xGreen, H, Harper, I \& Smirl, L 2009, 'Financial Deregulation and Household Debt: The Australian Experience', Australian Economic Review, vol. 42, no.3, pp. 340-346. http://dx.doi.org/10.1111/j.1467-8462.2009.00561.xGuest, R 2011, 'The Global Financial Crisis and Undergraduate Macroeconomics', Australian Economic Review, vol. 44, no. 1, pp. 113-120. http://dx.doi.org/10.1111/j.1467-8462.2010.00625.x

Hall, K 2008, 'The Importance of Financial Literacy', Reserve Bank of Australia: In Speeches. RBA, Sydney.

Hassan Al-Tamini, HA \& Kalli, AAB 2009, 'Financial Literacy and Investment Decisions of UAE Investors', Journal of Risk Finance, vol. 10, no. 5, pp. 500-516. http://dx.doi.org/10.1108/15265940911001402

Hoelzl, E, \& Kapteyn, A 2011, 'Financial capability', Journal of Economic Psychology, vol. 32, no. 4, pp. 543545. http://dx.doi.org/10.1016/j.joep.2011.04.005

Huston, SJ 2010, 'Measuring Financial Literacy', Journal of Consumer Affairs, vol. 44, no. 2, pp. $296-316$. http://dx.doi.org/10.1111/j.1745-6606.2010.01170.x

Jacobsen, DH, \& Naug, BE 2004, 'What influences the growth of household debt?', Norges Bank. Economic Bulletin. Norges Bank, Oslo. 
Kamleitner, B, \& Kirchler, E 2007, 'Consumer credit use: a process model and literature review', Revue Européenne de Psychologie Appliquée/European Review of Applied Psychology, vol. 57, no. 4, pp. 267283. http://dx.doi.org/10.1016/j.erap.2006.09.003

Lea, SEG, Webley, P, \& Walker, CM 1995, 'Psychological factors in consumer debt: Money management, economic socialization, and credit use', Journal of Economic Psychology, vol. 16, no. 4, pp. 681-701. http://dx.doi.org/10.1016/0167-4870(95)00013-4

Legge, J, \& Heynes, A 2009, 'Beyond reasonable debt: A background report on the indebtedness of New Zealand Families', Social Policy Journal of New Zealand, vol. 35, pp. 27-42.

Meng, X, \& Mounter, S 2009, ‘Australian Household Debt: A Sectoral-Level Study’, The Asia Pacific Journal of Economics \& Business, Vol. 13, no. 2, pp3.

Monticone, C 2010, 'How Much Does Wealth Matter in the Acquisition of Financial Literacy?', Journal of Consumer Affairs, vol. 44, no. 2, pp. 403-422. http://dx.doi.org/10.1111/j.1745-6606.2010.01175.x

Norvilitis, JM \& Santa Maria, P 2002, 'Credit Card Debt on College Campuses: Causes, Consequences, and Solutions’, College Student Journal, vol. 36, no. 3, pp. 356-358.

Norvilitis, JM, \& Szablicki, PB \& Wilson, SD 2003, 'Factors influencing levels of credit-card debt in college students', Journal of Applied Social Psychology, vol. 33, no. 5, pp. 935-947. http://dx.doi.org/10.1111/j.1559-1816.2003.tb01932.x

Norvilitis, JM, Merwin, MM, Osberg, TM, Roehling, PV, Young, P \& Kamas, MM 2006, 'Personality Factors, Money Attitudes, Financial Knowledge, and Credit-Card Debt in College Students', Journal of Applied Social Psychology, vol. 36, no.6, pp. 1395-1413. http://dx.doi.org/10.1111/j.0021-9029.2006.00065.x

O’Loughlin, D, \& Szmigin, I 2006, 'I'll always be in debt: Irish and UK student behaviour in a credit led environment', Journal of Consumer Marketing, vol. 23, no. 6, pp. 335-343. http://dx.doi.org/10.1108/07363760610701878

Palys, T 2008, 'Purposive Sampling', in LM Given (ed.), The SAGE Encyclopedia of Qualitative Research Methods, vol. 2, Thousand Oaks, CA, pp. 526-529. http://dx.doi.org/10.4135/9781412963909.n349

Pellinen, A, Tormakangas, K, Uusitalo, O \& Raijas, A 2011, 'Measuring the financial capability of investors: A case of the customers of mutual funds in Finland', International Journal of Bank Marketing, vol. 29, no. 2, pp. 107-133. http://dx.doi.org/10.1108/02652321111107611Perry, VG 2008, 'Giving Credit Where Credit is Due: The Psychology of Credit Ratings’, Journal of Behavioral Finance, vol. 9, no. 1, pp. 15-21. http://dx.doi.org/10.1080/15427560801896784

Perry, VG, \& Morris, MD 2005, 'Who Is in Control? The Role of Self-Perception, Knowledge, and Income in Explaining Consumer Financial Behavior’, Journal of Consumer Affairs, vol. 39, no. 2, pp. 299-313. http://dx.doi.org/10.1111/j.1745-6606.2005.00016.x

Remund, DL 2010, 'Financial literacy explicated: The case for a clearer definition in an increasingly complex economy', The Journal of Consumer Affairs, vol. 44, no. 2, pp. 276-295. http://dx.doi.org/10.1111/j.17456606.2010.01169.x

Reserve Bank of Australia 2012a, Statistical Tables: Household Finances - Selected Ratios B21, accessed 08/09/2012, <http://www.rba.gov.au/statistics/tables/index.html>.

Reserve Bank of Australia 2012b, Statistical Tables: Payments System - Credit and Charge Statistics C1, accessed, 08/09/2012 <http://www.rba.gov.au/statistics/tables/index.html>.

Starr, MA 2007, 'Saving, spending, and self-control: Cognition versus consumer culture', Review of Radical Political Economics, vol. 39, no. 2, pp. 214-229. http://dx.doi.org/10.1177/0486613407302484

Walker, CM 1996, 'Financial management, coping and debt in households under financial strain', Journal of Economic Psychology, vol. 17, pp. 789-807. http://dx.doi.org/10.1016/S0167-4870(96)00036-0

Watkins, JP 2009, 'Corporate profits and personal misery: Credit, gender and the distribution of income', Journal of Economic Issues, vol. 43, no. 2, pp. 413-422. http://dx.doi.org/10.2753/JEI0021-3624430214

Worthington, AC 2006, 'Predicting Financial Literacy in Australia', Financial Services Review, vol. 15, no. 1, pp. 59-79.

Worthington, AC 2008, 'Recent Developments in Australian Household Debt', JASSA, pp. 70-75.

Worthington, AC 2009, 'The Usage and Understanding of Australian Household Mortgages', International Journal of Housing Markets and Analysis, vol. 2, no. 4, pp. 347-362. http://dx.doi.org/10.1108/17538270910992791 


\section{Appendix}

\section{Survey questions used to calculate participants' Effective Debt Score}

\begin{tabular}{|c|c|c|c|}
\hline Debt & Questions & Effective & Ineffective \\
\hline 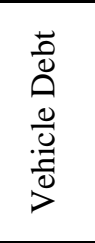 & $\begin{array}{l}\text { I obtained the vehicle loan or lease for work use because it is a tax } \\
\text { effective way to obtain a vehicle. } \\
\text { I have salary packaged the vehicle to obtain the most after tax } \\
\text { advantage. } \\
\text { I obtained the vehicle loan or lease for convenience reasons. } \\
\text { I feel that I can afford to pay the outstanding vehicle loan balance. }\end{array}$ & Effective & Ineffective \\
\hline 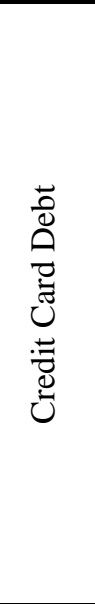 & $\begin{array}{l}\text { Ability to accumulate frequent flyers points and/or award points was } \\
\text { important in my choice of credit card. } \\
\text { I benefit from the interest free period that my credit card gives me. } \\
\text { I use my credit card for purchases when I have no available cash or } \\
\text { savings. } \\
\text { I have used my credit card to purchase sale items without paying the } \\
\text { credit card balance in full when due. } \\
\text { I sometimes buy items (e.g. clothes) with my credit card that I would } \\
\text { not normally buy if I didn't have a credit card. } \\
\text { I have withdrawn 'cash advances' on my credit card when making } \\
\text { purchases. } \\
\text { I feel comfortable with the level of debt on my credit card. } \\
\text { I have purchased tax deductible items at the end of the financial year } \\
\text { with my credit card without paying balance in full when due. } \\
\text { I often regret purchases I made on my credit card. }\end{array}$ & Effective & $\begin{array}{l}\text { Ineffective } \\
\text { Ineffective }\end{array}$ \\
\hline 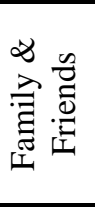 & $\begin{array}{l}\text { I have a written agreement (e.g. IOU) outlining the interest rate and } \\
\text { loan period with my family or friends. } \\
\text { I have borrowed 'interest-free' from family and friends for short terms } \\
\text { only to cover the cost of unexpected expenses. } \\
\text { I have borrowed from family or friends to settle my credit card debt. }\end{array}$ & $\begin{array}{l}\text { Effective } \\
\text { Effective }\end{array}$ & \\
\hline 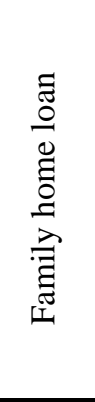 & $\begin{array}{l}\text { I feel confident that I can afford any interest rate increase. } \\
\text { I have purchased my home to save on rental expenses. } \\
\text { I have purchased my home because the property value may increase } \\
\text { over time. } \\
\text { I have used the equity in my home to finance holidays or for personal } \\
\text { purposes. } \\
\text { I have made extra repayments on my home loan in order to repay it in a } \\
\text { short time. } \\
\text { I have used equity in my home to purchase investments (e.g. rental } \\
\text { property, shares). }\end{array}$ & $\begin{array}{l}\text { Effective } \\
\text { Effective } \\
\text { Effective }\end{array}$ & Ineffective \\
\hline 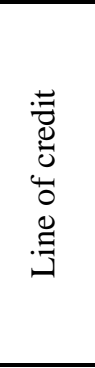 & $\begin{array}{l}\text { I have used my line of credit to finance holidays. } \\
\text { I have used my line of credit to purchase investments (e.g. rental } \\
\text { property, shares). } \\
\text { The level of my line of credit was based on my ability to make monthly } \\
\text { loan repayments. } \\
\text { I have requested the lender to increase my line of credit limit to } \\
\text { purchase investments (e.g. rental property, shares). } \\
\text { I have requested the lender to increase my line of credit limit for } \\
\text { personal purposes. }\end{array}$ & Effective & Ineffective \\
\hline \multicolumn{4}{|c|}{$\begin{array}{l}\text { Questions continued on next page } \\
\text { Survey questions used to calculate Effective Debt Score, continued }\end{array}$} \\
\hline Debt & Questions & Effective & Ineffective \\
\hline 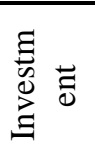 & $\begin{array}{l}\text { Negative gearing and tax benefits influenced me to obtain the } \\
\text { investment loan. } \\
\text { The level of my investment loan was based on my ability to make } \\
\text { monthly loan repayments. }\end{array}$ & Effective & \\
\hline
\end{tabular}




\begin{tabular}{|c|c|c|c|}
\hline & $\begin{array}{l}\text { I make both principal and interest repayments on my investment loan. } \\
\text { I feel confident that I can afford any interest rate increase. }\end{array}$ & $\begin{array}{l}\text { Effective } \\
\text { Effective }\end{array}$ & \\
\hline 葋 & $\begin{array}{l}\text { I have earned a higher income (or expect to earn) after finishing } \\
\text { university. } \\
\text { A } 10 \% \text { discount has influenced me to pay at least a } \$ 500 \text { student } \\
\text { contribution payment. } \\
\text { I was influenced by interest-free HECS or HELP debt to defer student } \\
\text { debt repayment. }\end{array}$ & $\begin{array}{l}\text { Effective } \\
\text { Effective }\end{array}$ & \\
\hline 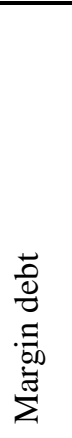 & $\begin{array}{l}\text { I have used my margin loan to purchase shares or managed funds. } \\
\text { Negative gearing and tax benefits influenced me to obtain the margin } \\
\text { loan. } \\
\text { The level of my margin loan was based on my ability to keep me safe } \\
\text { from the possibility of receiving a margin call. } \\
\text { If I receive a margin call, I would have to sell the purchased shares or } \\
\text { managed funds. } \\
\text { The level of my margin loan was based on the maximum amount the } \\
\text { lender offered me. } \\
\text { The level of my margin loan was based on my ability to make monthly } \\
\text { loan repayments. }\end{array}$ & $\begin{array}{l}\text { Effective } \\
\text { Effective }\end{array}$ & $\begin{array}{l}\text { Ineffective } \\
\text { Ineffective }\end{array}$ \\
\hline 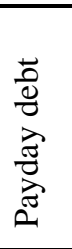 & $\begin{array}{l}\text { I obtained the payday loan to pay for unexpected expenses (e.g. car or } \\
\text { home repairs). } \\
\text { I obtained the payday loan to cover the cost of holiday expenses. } \\
\text { I obtained the payday loan to bridge the financial gap between two } \\
\text { paydays. } \\
\text { I feel getting a payday loan was a good decision. }\end{array}$ & $\begin{array}{l}\text { Effective } \\
\text { Effective }\end{array}$ & $\begin{array}{l}\text { Ineffective } \\
\text { Ineffective }\end{array}$ \\
\hline
\end{tabular}

